\title{
REVIEW
}

\section{Marine biology on a violated planet: from science to conscience}

\author{
Giovanni Bearzi* \\ Dolphin Biology and Conservation, via Cellina 5, 33084 Cordenons, Italy \\ OceanCare, Gerbestrasse 6, 8820 Wädenswil, Switzerland \\ Institute of Marine Sciences, National Research Council (ISMAR-CNR), Castello 2737/F, 30122 Venice, Italy
}

\begin{abstract}
Humanity's self-ordained mandate to subdue and dominate nature is part of the cognitive foundation of the modern world - a perspective that remains deeply ingrained in science and technology. Marine biology has not been immune to this anthropocentric bias. But this needs to change, and the gaps between basic scientific disciplines and the global conservation imperatives of our time need to be bridged. In the face of a looming ecological and climate crisis, marine biologists must upgrade their values and professional standards and help foster the radical transformation needed to avert a climate and ecological breakdown. To prevent some of the damage, they must cross the imaginary line that separates science from science-based activism and consciously pursue the health and durability of human and natural communities. To this end, they can (1) develop compelling narratives that engage human society, with emphasis on care for the wild living world ${ }_{i}(2)$ move beyond marine conservation on paper and avoid self-serving complaisance; (3) advocate constructive changes in market and human behaviour, not only by documenting damage but also by clarifying how the extraction, production and consumption system can be steered away from practices that harm nature; (4) push for systemic change in politics through individual and collective efforts, supporting environmental activism and those who demand biosphere-saving policies; and (5) endorse a more ecocentric and holistic world vision, relinquishing contempt for spiritual wisdom and liaising with (or at least not dismissing) spiritual traditions that encourage equality, self-restraint and environmental sustainability.
\end{abstract}

KEY WORDS: Marine biology $\cdot$ Marine conservation $\cdot$ Environmental crisis $\cdot$ Climate change $\cdot$ Biodiversity conservation $\cdot$ Overexploitation $\cdot$ Sustainability $\cdot$ Outreach $\cdot$ Activism

\section{PREFACE}

'Suppose that the ultimate standard of our work were to be, not professionalism and profitability, but the health and durability of human and natural communities'.

Wendell Berry

In my training years as a biologist, back in the 1980s, I could not discern a clear mandate to place my professional skills at the service of 'the health and

*Corresponding author: giovanni.bearzi@gmail.com durability of human and natural communities'. None of my teachers seemed to encourage commitment to a greater good in the holistic sense implied by Wendell Berry. Rather, I was conditioned to accept the notion that science was good per se and knowledge invariably beneficial. Research could appear to be futile or at times even self-serving, but that was okay, and profitability was beyond question a standard of achievement. Hyper-specialization epitomized a successful career in science, and it is no wonder that many scientists of my generation have become

() The author 2020. Open Access under Creative Commons by Attribution Licence. Use, distribution and reproduction are unrestricted. Authors and original publication must be credited. 
immersed in the technicalities of narrow subjects of study, often losing any vital or immediate connection with principles of ecology and biology. Beyond the realm of knowledge, the overarching goal was (in fact still is) to publish decent scientific papers, thereby improving one's career opportunities, feeding one's ambition of becoming a reputable or even renowned biologist, landing the best possible job and joining the community of scientists. Becoming members of such a community brought the satisfaction of belonging, but there seemed to be at most only a modest obligation to prioritize, strategize and ultimately use science to advance well-defined conservation objectives.

We were also not trained to present our results in appealing and widely understandable ways. Being poor at communication seemed not to be a problem, and few cared about reaching out to audiences wider than one's own scientific colleagues. Marine biology (and other) conferences featured the occasional death by PowerPoint, and one could rarely detect a serious commitment to excel in outreach and in getting the message across. In addition, incorporating passion and affection for nature into one's writing and presentations was generally deemed to be bad scientific practice, and those who were overt or explicit about their love for the planet or passionate about saving the ocean, the manatees or anything else could end up ostracized. Therefore, even if there was an intention to work effectively towards marine conservation, deliberate purpose was often hidden or lost in translation - particularly within academia and formal institutions. I have always been passionate about my research subjects, Mediterranean dolphins, and my outspoken goal of preventing their decline would occasionally qualify me as a tree-hugger (a derogatory epithet; DeLoach et al. 2002, Hutchings 2005). In the past, the raised eyebrows of traditional colleagues would remind me that environmental activism was a sin, leading to (or being led by) biased science. Today, however, such old-school understanding appears fabricated and self-defeating, and the global sensibility has changed to the point that being called a tree-hugger may be seen as honourable.

\section{A GRADUAL AWAKENING}

By the 1970s, humanity had been alerted repeatedly about the risks resulting from a booming population (Ehrlich 1978) and other existential threats. While these alarms had provoked waves of concern, some of the announced catastrophes did not happen in the way they were forecasted (e.g. the limits to growth warnings of neo-Malthusianism; Meadows et al. 1972, 2005, Morris 2009). Other announced catastrophes were averted (e.g. the risks of ozone depletion through the phasing out of industrial chlorofluorocarbons; Solomon et al. 2016). The warnings of doomsayers who portended approaching misfortunes prompted rebuttals by cornucopians (or exemptionalists; Cairns 1999) inclined to trust human wit, celebrate technological progress and believe in the endless availability of resources (Aligica 2009, Kelly 2013). Meanwhile, evidence of unsustainable human impact on the planet had been piling up, and the warnings of upcoming disaster were becoming ever more credible and worrying (Vitousek et al. 1997, Ripple et al. 2017). Yet, modern-day cornucopians went on offering compelling narratives that portrayed human history largely as a success story through a plethora of graphs in which trendlines almost invariably implied patterns of progress and improvement (Pinker 2011, 2018, Rosling et al. 2018). Pollyannaish visions such as those of Steven Pinker were consistent with the neoliberal capitalism, free market credo that had been unleashed in the 1980s and therefore were much appreciated by the tycoons of powerful industrial elites (e.g. Gates 2018). Other thinkers criticized Pinker for his dogmatism, perfidious politics and selective use of data (e.g. Sapolsky 2017, Lent 2018, McGoey 2019, Riskin 2019).

One of the main problems with these narratives, however, is their scarce consideration for the mounting environmental and climate crisis (Monbiot 2018). Cornucopian views contributed to the numbing of human societies that were already exposed to the cultural diversions of complaisant media and to the mystifications of industry-driven think tanks that, among other denials, had been deliberately concealing climate change (Oreskes \& Conway 2010, Washington \& Cook 2011, Dunlap \& McCright 2015, Marshall 2015). Under such a sanitized and distorted cultural scenario, even the most compelling evidence of rising greenhouse gases could be downplayed, and the risks could go unperceived. For instance, an authoritative marine conservation biology book, published as recently as 2005 (Norse \& Crowder 2005), is 'surprisingly silent on the effects of global warming and climate change' (Jessen et al. 2006, p 230) as a threat to marine biodiversity. Apart from the climatologists and the visionaries (McKibben 1989), not many could discern an immediate climate emergency of the ominous kind that has loomed over us in these last few years. In the face of warnings unmatched by proportionate reactions within our intel- 
lectual milieu, many marine biologists (including myself) went on behaving as if there was still plenty of time to solve the environmental and climate crisis. Perhaps we just weren't ready to leave our comfort zone and venture into a complex realm of inconvenient truths. My own awakening to these truths happened gradually, then suddenly. And it came as a shock.

\section{FACING THE HEAT}

To my dismay, I was becoming aware that living systems and the physical environment had been depleted and disrupted, resulting in losses of biodiversity, mass extinctions and catastrophic climate and ecological changes (Ceballos et al. 2017, Ripple et al. 2017, 2020, Bar-On et al. 2018, IPCC 2018, 2019, Mora et al. 2018, Kulp \& Strauss 2019, Lenton et al. 2019). Today's world is as wounded as ever (Ehrlich 1997, McKibben 2019), and some of the longpredicted climate-driven calamities are happening with increasing intensity or frequency (e.g. extreme weather events, bushfires, droughts, floods, glacier melting, sea level rise, marine heatwaves). In retrospect, even the dire warnings of the 1970 s-dismissed as alarmism and infamously labelled as an eco-scam (Bailey 1993) - may have been imprecise but turned out to contain substantial truths (Meadows et al. 2005, Turner 2008, Ehrlich \& Ehrlich 2013, Nekola et al. 2013, Running 2013).

Whether or not these facts are accurately reported by the media or acknowledged by present-day political leaders and their electorates, those who are familiar with the scientific literature (and understand the message; Benestad et al. 2016) know that we are not en route to meet the $1.5^{\circ} \mathrm{C}$ climate target of the Paris Agreement (Hausfather 2019, Tong et al. 2019, UNEP 2019). Little time is left to prevent irreversible warming and avert the risk of a Hothouse Earth pathway (IPCC 2018, Steffen et al. 2018). This inconvenient truth is emphasized in signs held by the young people attending global strikes for climate: Normal is Over, There is No Planet B. Nobody should be fiddling while the planet is burning down and certainly not biologists and ecologists who know what is really at stake. As noted by Gary K. Meffe (1998) 2 decades ago, 'the time has long passed when we could merely pontificate in our journals, impress our colleagues, and proclaim that we are above the political fray' (p 741). This rings even truer today. Continuing to live and work as if everything is fine makes change impossible and breakdown inevitable.

\section{MARINE CONSERVATION-ON PAPER}

The overexploitation of marine life has encompassed centuries of human history and is aptly exemplified by commercial whaling, whose gargantuan appetite brought several species of large cetaceans to the brink of collapse. While the slaughters caused by whaling across 2 centuries have been fairly well documented (Tønnessen \& Johnsen 1982, Gambell 1999, Baker \& Clapham 2004), overexploitation of fish and other marine life has long remained unspoken or chronicled only through anecdote (Mowat 1984, Pauly 1995). Since the late 1990s, however, accounts of unsustainable fishing became compelling and dismaying (Pauly et al. 1998, Jackson et al. 2001, 2011, Christensen et al. 2014, Pauly 2019), as did a variety of other human-made marine calamities (e.g. climate-driven coral bleaching; Hughes et al. 2003, 2018a,b, Hoegh-Guldberg et al. 2007). The mainstream media slowly tuned in to these facts and - after decades spent portraying bounteous and awe-inspiring oceans - started offering glimpses of marine biodiversity loss and ecosystem damage.

Some of my studies in the Mediterranean, originally intended to focus on the ecology of dolphin communities, ended up documenting their decline. After years of field research, we could identify the human activities responsible for the damage (for instance, prey depletion caused by industrial overfishing), but even when we proposed straightforward solutions within simple management regimes, no action was taken to protect the surviving animals or their habitats (Bearzi et al. 2003, 2006, 2008, Piroddi et al. 2011). Through trial and error, we realized that science and information alone rarely contributed to environmental healing. As marine biologists, we were encouraged to produce ever more data and keep our focus on papers and reports, so that action could be delayed indefinitely - a practice I characterized as marine conservation on paper (Bearzi 2007). To be sure, environmental agreements and formal commitments by governments expressed the best intentions of preserving habitats and repairing the damage, but the interests of industrial lobbies came first and foremost. At that point, it felt like we could have been playing into the hands of a dangerously self-serving system.

George Monbiot (2006) referred to this system when he argued that 'government policy is not contained within the reports and reviews it commissions; government policy is the reports and reviews... [T] he government creates the impression that something is being done, while simultaneously preventing any- 
thing from happening'. Thousands of national and international environmental agreements are currently in place (Mitchell 2019), and in many cases these agreements have been effective and valuable (e.g. Roman et al. 2013). Yet, on a global scale, human encroachment has led to scenarios described as biological annihilation and the sixth mass extinction (Ceballos et al. 2017).

Ocean protection tools have included the certification of sustainable fisheries (through the ecolabelling of seafood) and the creation of marine protected areas (MPAs). Seafood certification, however, has largely failed to ensure true sustainability, as did consumer awareness campaigns (Jacquet et al. 2010a,b, Le Manach et al. 2020). MPAs make superb conservation tools (Roberts et al. 2005), but sometimes they are paper parks that provide little protection (Guidetti et al. 2008, Agardy et al. 2011, Devillers et al. 2015, Claudet et al. 2020). Human impact may even increase within MPAs (Dureuil et al. 2018) - a most unexpected finding. Unfortunately, management action is sometimes farcicalfor example, banning windsurfing, kayaking or sport angling within protected areas that are unaffected by sport tourism while allowing continued exposure to overfishing or high-intensity noise from oil and gas prospection. That is the marine equivalent of designating a forest as a protected area while allowing loggers to fell all the trees.

It is worth remembering that, historically, ocean exploitation has been strongly influenced by scientific advice and that fisheries science has spectacularly failed to protect or manage fish populations (Kurlansky 1997, FAO 2018, Pauly 2019). The eminent 19th century biologist Thomas Henry Huxley provided one of the most striking examples when he argued for reducing fisheries regulations, complaining that there was no scientific basis for them and that they unnecessarily hurt fishermen (Smith 2002). Huxley (1885) went as far as making his notorious, influential and disgraceful proclamation on the infinite bounty of the sea: 'I believe, then, that the cod fishery, the herring fishery, the pilchard fishery, the mackerel fishery, and probably all the great sea fisheries, are inexhaustible; that is to say, that nothing we do seriously affects the number of the fish. And any attempt to regulate these fisheries seems consequently, from the nature of the case, to be useless'.

This heritage lives on, albeit in disguise, whenever a profit-driven apparatus skilfully orchestrates, manipulates and makes use of science to support or greenwash industrial and corporate interests. Within such systems, the self-serving and complaisant research programmes are not only as good as any but also turn out to be especially desirable. Concurrently, conservation on paper (consisting of calls for disposable action plans and throwaway management recommendations) ensures that scientists engage in recursive science schemes under the illusion of contributing to conservation breakthroughs. While the scenario might have changed in recent years, repairing the damage has become a gigantic challenge.

\section{CHANGING THE GAME}

The time has come-and indeed passed-to consciously upgrade our values, methods and behaviour. As our global leaders demonstrate their inability to respond to the crisis and ward off the drivers of self-destruction, it is becoming clear that the ideas needed to reshape our future must stretch beyond the confines of our current system. A paradigm shift is necessary, and the stage has already been set for cultural, economic and political metamorphoses that can lead to global recovery (e.g. Brown 2008, Korten 2010, 2015, Scheer 2012, Raworth 2017, Díaz et al. 2019, Dinerstein et al. 2019, O'Neill et al. 2019, Pettifor 2019). A critical part of the challenge, within the reach of marine biologists, is preserving what is left of life at sea and help rewild the oceans (Monbiot 2013, Jørgensen 2015, Laffoley et al. 2020).

The link between marine biology and global conservation is promptly made if one considers (1) the role played by the oceans and by marine organisms in sequestering and fixing atmospheric carbon and generally keeping the Earth in balance (Reid et al. 2009, Levin \& Le Bris 2015), (2) the impacts of climate change on marine organisms and ecosystems (Brierley \& Kingsford 2009), (3) the innumerable ways in which human activities at sea contribute to the worsening of the environmental and climate crisis (Halpern et al. 2008, 2015, Doney 2010), and (4) the importance of marine scientists when it comes to understanding, documenting and communicating the crisis. The question then is: How can we capitalize on our expertise, join forces and contribute most effectively to the solutions? What does it take to bridge the gap between conservative scientific disciplines and the global conservation imperatives of our time? Below, I offer a few hints in a spirit of constructive self-criticism (I wish I had done myself, long ago, all that is being preached here). 


\subsection{Proclaiming that we care}

To get out of this mess, we must first relinquish our belief in progress as everlasting and unconstrained growth and replace it with value systems leading to environmental sustainability and social justice. As marine biologists, we can help envision a world where the role played by humans is consistent with the laws of nature and the reality of a finite planet. Paraphrasing Wendell Berry (2001), we must not only suppose or imagine but loudly proclaim that the ultimate standard of our work is the health and durability of human and natural communities. We should take responsibility and become marine conservation stewards who are thoughtful of the consequences of their choices and actions. Such commitment must be placed at the core of our profession, to the point that everything we do truly does have the goal of benefiting the larger community of humans and life on Earth rather than ourselves, our circles or our nation.

\subsection{Communicating effectively}

For decades, we have been working in a scientific environment that discouraged individual researchers from expressing views that could be interpreted as green activism or have political connotations (Pielke 2004). However, not expressing one's opinion and not engaging in activism also is a political choice, as it often implies supporting (or at least not challenging) the status quo and therefore implicitly endorsing it (Anderson 2003, Oransky \& Marcus 2017, Ernman et al. 2020).

Contrary to what we have been conditioned to think, supplying information is not enough. Even climate scientists, whose early warnings went unheeded in part because of ineffective messaging, have realized that their science does not communicate itself and that high-quality outreach is essential (Hassol 2008, Somerville \& Hassol 2011, Corner et al. 2018). We, too, need to leave behind jargon and sectarian arguments and enhance our communication, lifting the antiquated taboo on saving the planet language and placing emphasis on defending what we love (e.g. Earle 2009, Johnson 2019). Our care for the living world should not only be made explicit but also become the core of compelling narratives we use to engage human society. We must aim to tell heartfelt, captivating stories centred on our own experience, bringing to life a capacity to think outside the box and dream big. To reach people at a deeper emotional level, we may even team up with conservation non-governmental organizations and groups of environmental activists or collaborate with designers, art directors, artists and celebrities as well as fellow scientists in various disciplines.

Our communication strategy may include the adoption of evocative wording. We can be scientifically accurate while also telling a rich story and conveying a sense of urgency that matches the scale of today's environmental crises. For example, ecocide, eco-crime (or environmental crime) and other terms borrowed from green criminology (Mares 2010, Higgins et al. 2013, White 2013, 2016) may be incorporated into the vocabulary of marine scientists to replace vague and timid terminology such as anthropogenic impact with more vivid and faithful wording, when appropriate. In addition, transposing key concepts of environmental criminology into the practice of marine biology would help deliver an unequivocal message that action must be taken in pursuit of ecological and social justice, and those in charge must be held accountable (Ruggiero \& South 2010a,b, 2013). Therefore, practices such as those leading to the extirpation or extinction of aquatic animals (Brownell et al. 2019), the devastation of deep-sea habitats (Roberts 2002, Halfar \& Fujita 2007) or the collapse of coastal ecosystems (Jackson et al. 2001, Pauly 2019) should be qualified for what they are: crimes against humanity and nature.

As we reprove irresponsible human behaviour and express concern for the living world, we should also realize that conveying messages of terror and panic may not be the most productive approach because, when those feelings are sent out in raw form, they may cause trauma and paralyzing anxiety. As marine scientists committed to conservation and to sensible outreach, we would do a better job if we synthesize the bad news and transform it into inspiring calls that stimulate beneficial action rather than nihilism or surrender. Ideally, an overview of the problems (which still must be referred to accurately) should be followed by practicable solutions and by positive examples that illustrate ways of shifting our values and behaviour towards less destructive economic systems (e.g. Duarte et al. 2020, Stewart et al. 2020).

\subsection{Embracing real sustainability}

Because economics and environmental conservation are largely intertwined, we cannot deal effectively with a crisis unless we confront the economic, social and political reality that generated the crisis (Commoner 1973). As marine biologists, we should 
not only document a threat to marine life but also help clarify how the extraction, production and consumption system can be steered away from damaging and unsustainable practices. On a more fundamental level, we should accurately characterize the decisions driven by industrial or commercial interests and reject any system that sees nature as a resource to be pillaged in pursuit of perpetual growth and material wealth. For instance, once the negative consequences of a given type of fishing gear have been documented through research, the most straightforward approach would be calling for a ban of that fishing gear. If that proves impossible (which it usually is, given the disparities in values and conditions of people across the world), the next option would be to enforce time and space restrictions, eliminate economic incentives that enhance fishing capacity and effort, and replace harmful subsidies and funding with beneficial subsidies (Cullis-Suzuki \& Pauly 2010, Sumaila et al. 2016). Finally, we should help decrease the market demand for species captured with damaging gear, primarily through legislation and taxation and not only through awareness campaigns (given that, inevitably, the latter campaigns are only partially effective; Jacquet et al. 2010a,b). Changing the status quo and tackling the causes - instead of merely mitigating the effects - requires judicious and imaginative planning, leading to thoughtful strategies for research, outreach and management.

Now, compare the pathway described above with the following example. Some trawlers in the northwestern Adriatic Sea display a large sticker reading 'This boat takes care of the sea', because they have agreed to land some of the litter, including plastics, caught in their nets instead of routinely discarding it at sea. The sticker is given to fishers 'as a recognition of their commitment to protect and preserve the marine environment', in the context of EUfunded projects. Attempts to remove plastic from the marine environment are laudable. However, promoting trawling as a way to protect and preserve the marine environment within one of the most over-trawled areas in the world (Eigaard et al. 2017, Gissi et al. 2017, Amoroso et al. 2018, Ferrà et al. 2018, Russo et al. 2019), where damage caused by overfishing and trawling has been well documented and marine biodiversity has declined sharply (Bearzi et al. 2004, Coll et al. 2009, Barausse et al. 2011, 2014, Lotze et al. 2011, Ferretti et al. 2013, Fortibuoni et al. 2017), sends confusing messages while not addressing the problems at their root. In this case, the processes leading to plastic production and consumption (which include industry lobbying, consumer preferences and ease of handling and disposal) remain unaffected, while trawling - in a twist of perspective - is portrayed as marine conservation.

The available grants and opportunities in the marine sector - sometimes provisioned by institutional funding schemes that lack foresight-may steer marine conservation efforts in subtle ways. As marine scientists, however, we should aim to lead rather than mislead. While the experts involved in the Adriatic project mentioned above are certainly driven by good intentions, these initiatives proclaim that relevant conservation problems are being addressed, when only the surface is being scratched. The available funding and expertise must be used first and foremost to develop non-destructive sustainable fisheries and facilitate ecosystem recovery. Where marine litter is an important conservation concern (e.g. Brown \& Macfadyen 2007), removal strategies should not include the endorsement or reinforcement of destructive fishing methods known to cause mechanical and biological damage to the seabed (Jones 1992, Hall-Spencer et al. 1999, Pranovi et al. 2000, Kaiser 2002, Lucchetti \& Sala 2012).

\subsection{Fostering individual and system change}

Many of us have attended conferences and workshops organized in fancy resorts located in exotic locations that require multiple flights. Conference attendees may even banquet on bottom-dwelling shrimp right after having learned about the damage caused by bottom trawls (e.g. Chuenpagdee et al. 2003) and shrimp aquaculture (e.g. Páez-Osuna 2001). No matter how effective such gatherings may seem to be in advancing marine conservation biology, they carry an embedded inconsistency, as if those responsible for environmental damage are invariably others, somewhere else. Such inconsistencies are increasingly debated, particularly with regard to restraint in flying (to reduce our carbon footprints; Fox et al. 2009, Bossdorf et al. 2010, Achten et al. 2013) or switching to a plant-based diet (to reduce the environmental and climate impacts of meat and seafood production and consumption; Stehfest et al. 2009, Hedenus et al. 2014, Ripple et al. 2014, Machovina et al. 2015, Jacquet et al. 2017, Poore \& Nemecek 2018).

Marine biologists and other scientists who appear to overlook their own footprint often contend that individual behaviour does not matter; it is the system that needs to be changed. That is correct. A change 
in the system (and a new breed of political leaders) is unquestionably needed to tackle the environmental and climate crises. It is also true that neoliberalism and corporate agendas have conned us into tackling the crisis as individuals - whereas most of the damage originates from the choices of a handful of giant companies and mighty executives (Lukacs 2017). That, however, does not mean individual and social behaviour is irrelevant.

First, the effects of individual behaviour are rarely experienced only by the individual him- or herself. Our choices affect and influence those around us. This must be even truer for marine biology professionals, whose actions may be taken as a model by colleagues and students (Bearzi 2009). Second, a change in the system can only be instigated through the coordinated efforts of a group of individuals, and more often than not, it is the initiative and example of a single individual that triggers collective efforts. Third, as noted by Jussi Pasanen (2019), one cannot truly choose between individual change and system change. Rather, one can choose to (1) become aware and develop a deeper and more holistic understanding of a problem, (2) do something about it on a personal level, thus helping to drive market and policy choices, and (3) encourage change in others while pushing for transformation in the system. The latter can be done more effectively by directly influencing political decision-making (Rieser et al. 2005), lobbying for greener and more responsible leaders, connecting with people and organizations that help us become empowered and engaging in coordinated action. Even if not all of us have the opportunities or the skills to succeed in each of the above-mentioned tasks, any of us can do his or her best-at all levels.

\subsection{Supporting environmental activism}

Steering humanity away from environmental and climate disasters requires committed activism, mobilization and civil resistance. Well-planned environmental campaigning can pave the way for significant change. Examples include the anti-whaling movement and a variety of other initiatives that contributed to public appreciation and emerging compassion towards cetaceans and other marine mammals, leading to lower mortality and measurable conservation benefits (Twiss \& Reeves 1999, Epstein 2005, Bearzi et al. 2010, Reeves 2018). Even the unwavering activism of single individuals sometimes results in unpredictable uprising, setting in motion perception shifts and changes in collective behaviour.
Within $1 \mathrm{yr}$, the solitary strike for climate of young activist Greta Thunberg has developed into a global protest joined by millions of people (Alter et al. 2019). While some may mock or dismiss these initiatives, research shows that non-violent mobilization has enormous potential. In the past $100 \mathrm{yr}$, non-violent campaigns have been twice as successful as violent uprisings, and the active and sustained participation of just $3.5 \%$ of a population can result in important political or societal change (Stephan \& Chenoweth 2008, Chenoweth \& Stephan 2011). As marine biologists and knowledgeable scientists, there is much we can do to support, motivate and inform the non-violent activists who demand policies ensuring that our planet remains habitable (Hagedorn et al. 2019, Warren 2019). We may even join the protest ourselves.

\subsection{Relinquishing contempt for spirituality}

For centuries, humanity's mandate to subdue nature and have dominion over its living resources, as expressed in the Bible (Genesis 1:26-28), provided a theological and moral justification for exploiting the natural world (White 1967, Eckberg \& Blocker 1989). This right to dominion and sovereignty over nature has become part of the cognitive foundation of the western world, as epitomized by Francis Bacon (1857) when he wrote, 'Man, if we look to final causes, may be regarded as the centre of the world (...) For the whole world works together in the service of man; and there is nothing from which he does not derive use and fruit (...) insomuch that all things seem to be going about man's business and not their own'. These deeply rooted ideas, combined with René Descartes' portrait of nature as a machine, culminated in the 19th century western vision of humankind engaged heroically in conquering nature, which provided a further justification for reckless exploitation. Such conceptual frameworks are ingrained into modern science and into our culture, which still sees progress as an increased dominion over nature and regards the whole of nature as a commodity (White 1967, Lent 2017).

Acknowledging this theological bias of science or the subtle influence of some religious thinking, however, does not imply that the entire corpus of religion and spirituality should be opposed or discarded within the context of environmental science and conservation. The void of spiritual and ethical values produced by materialism and neoliberalism clearly cannot be filled by science alone. Conversely, values consistent with equality, self-restraint, non-harming, respect for all living beings and environmental 
sustainability are at the core of spiritual wisdom dating back thousands of years (Negi 2005). Some of the non-theistic and non-dualistic spiritual traditions from the East are often considered closer to the holistic approach needed to divert humanity from selfdestruction (e.g. Stanley et al. 2009, Payne 2010, Lent 2017). However, a different interpretation of Christianity also can be envisaged, consistent with the message of the greatest spiritual revolutionary in western history, Saint Francis of Assisi (White 1967). Francis (born 1181) proposed an alternative Christian view of nature and humans' relationship to it: the idea of the equality of all creatures, including humans. His message has been ignored for centuries but is as modern as ever - to the point that a different Francis has recently revived this vision in his encyclical Laudato Si': On Care for our Common Home (Pope Francis 2015).

Though few modern scientists have expressed interest in pursuing a dialogue between science and religion of the kind advocated by E. O. Wilson (2006) in his book The Creation: an Appeal to Save Life on Earth, religious leaders and scholars have increasingly embraced environmental conservation (Ecumenical Patriarch Bartholomew 2012, Pope Francis 2015, Dunne \& Goleman 2018). One religious leader has even exhibited openness to the idea of modifying obsolete dogma based on scientific evidence (Dalai Lama 2005). Whereas the approaches, conceptual frameworks and competences of science and religion will remain different (Berry 2001), a challenge as great as saving the Creation requires unity and consilience rather than division (Wilson 1999, McLeod \& Palmer 2015). In marine science circles, relinquishing contempt for spiritual teachings that recognize the interconnectedness of all forms of life, and endorsing a more ecocentric and holistic vision, would help advance the biosphere-saving synergies advocated by E. O. Wilson.

\section{HOPE IS OPTIONAL, ACTION IS NOT}

It is almost impossible to grasp, let alone fully accept, the bleak reality of what humans have collectively done to our only home (Marshall 2015, McKibben 2019). Being aware of the impending climate and ecological breakdown - and the reckless policies of limitless capitalism - may cause legitimate ecological grief, which includes sadness, hopelessness, fear and despair (Cunsolo \& Ellis 2018, Gordon et al. 2019). However, nihilism and inaction won't help, and those of us who do not react, or indulge in negativity, risk becoming ourselves a part of the problem. As Alexandria Ocasio-Cortez put it, 'Hope is not something that you have: hope is something that you create, with your actions' (Brockes 2019). In other words, hope is neither blind optimism nor a matter of estimating the odds. It is a choice and a state of mind inspired by the recognition that change is non-linear and often unpredictable (Hobbs 2013, Lent 2019).

Even if we cannot avert catastrophes that are beyond our control, as marine biology and conservation experts, we certainly can prevent some of the damage or contribute to environmental healing, thus leaving a better heritage to future generations and sparing some of the suffering to fellow humans and animals. This is and will remain possible - with or without hope. In this essay, I have proposed some ways that we, as individuals, can help to change the game, but more and better solutions and strategies can be envisaged once we 'cross the imaginary line' (Sedlak 2016) that separates science from conscience and science-based activism.

Acknowledgements. I am grateful to Silvia Bonizzoni and Randall R. Reeves for their thoughtful comments and excellent advice, and I am grateful for the equally thoughtful contributions of 2 anonymous reviewers. Maddalena Bearzi, Lavinia Eddy, Jennifer Jacquet, Sarah Piwetz, Konstantinos I. Stergiou, Nicola Stoppelli and Bernd Würsig contributed valuable suggestions.

\section{LITERATURE CITED}

Achten WM, Almeida J, Muys B (2013) Carbon footprint of science: more than flying. Ecol Indic 34:352-355

Agardy T, Notarbartolo di Sciara G, Christie P (2011) Mind the gap: addressing the shortcomings of marine protected areas through large scale marine spatial planning. Mar Policy 35:226-232

Aligica PD (2009) Julian Simon and the 'limits to growth' neo-Malthusianism. Electron J Sustain Dev 1:49-60

Alter C, Haynes S, Worland J (2019) 2019 person of the year: Greta Thunberg. Time. https://time.com/person-of-theyear-2019-greta-thunberg/

Amoroso RO, Pitcher CR, Rijnsdorp AD, McConnaughey RA and others (2018) Bottom trawl fishing footprints on the world's continental shelves. Proc Natl Acad Sci USA 115: E10275-E10282

Anderson CJ (2003) The psychology of doing nothing: Forms of decision avoidance result from reason and emotion. Psychol Bull 129:139-167

Bacon F (1857) Of the wisdom of the ancients. Longman, London. https://www.bartleby.com/82/26.html

Bailey R (1993) Eco-scam: the false prophets of ecological apocalypse. St Martin's Press, New York, NY

Baker CS, Clapham PJ (2004) Modelling the past and future of whales and whaling. Trends Ecol Evol 19:365-371

Bar-On YM, Phillips R, Milo R (2018) The biomass distribu- 
tion on Earth. Proc Natl Acad Sci USA 115:6506-6511

Barausse A, Michieli A, Riginella E, Palmeri L, Mazzoldi C (2011) Long-term changes in community composition and life-history traits in a highly exploited basin (northern Adriatic Sea): the role of environment and anthropogenic pressures. J Fish Biol 79:1453-1486

Barausse A, Correale V, Curkovic A, Finotto L, Riginella E, Visentin E, Mazzoldi C (2014) The role of fisheries and the environment in driving the decline of elasmobranchs in the northern Adriatic Sea. ICES J Mar Sci 71: 1593-1603

Bearzi G (2007) Marine conservation on paper. Conserv Biol $21: 1-3$

Bearzi G (2009) When swordfish conservation biologists eat swordfish. Conserv Biol 23:1-2

Bearzi G, Reeves RR, Notarbartolo di Sciara G, Politi E, Cañadas A, Frantzis A, Mussi B (2003) Ecology, status and conservation of short-beaked common dolphins (Delphinus delphis) in the Mediterranean Sea. Mammal Rev 33:224-252

Bearzi G, Holcer D, Notarbartolo di Sciara G (2004) The role of historical dolphin takes and habitat degradation in shaping the present status of northern Adriatic cetaceans. Aquat Conserv 14:363-379

Bearzi G, Politi E, Agazzi S, Azzellino A (2006) Prey depletion caused by overfishing and the decline of marine megafauna in eastern Ionian Sea coastal waters (central Mediterranean). Biol Conserv 127:373-382

Bearzi G, Agazzi S, Gonzalvo J, Costa M and others (2008) Overfishing and the disappearance of short-beaked common dolphins from western Greece. Endang Species Res 5:1-12

Bearzi G, Pierantonio N, Bonizzoni S, Notarbartolo di Sciara G, Demma M (2010) Perception of a cetacean mass stranding in Italy: the emergence of compassion. Aquat Conserv 20:644-654

* Benestad RE, Nuccitelli D, Lewandowsky S, Hayhoe K, Hygen HO, van Dorland R, Cook J (2016) Learning from mistakes in climate research. Theor Appl Climatol 126: 699-703

Berry W (2001) Life is a miracle: an essay against modern superstition. Counterpoint, Berkeley, CA

Bossdorf O, Parepa M, Fischer M (2010) Climate-neutral ecology conferences: Just do it. Trends Ecol Evol 25:61

Brierley AS, Kingsford MJ (2009) Impacts of climate change on marine organisms and ecosystems. Curr Biol 19: R602-R614

Brockes E (2019) When Alexandria Ocasio-Cortez met Greta Thunberg: 'Hope is contagious'. The Guardian, 29 June 2019. https://www.theguardian.com/environment/2019/ jun/29/alexandria-ocasio-cortez-met-greta-thunberghope-contagious-climate

Brown LR (2008) Plan B 3.0: mobilizing to save civilization. Norton, New York, NY

* Brown J, Macfadyen G (2007) Ghost fishing in European waters: impacts and management responses. Mar Policy 31:488-504

Brownell RL Jr, Reeves RR, Read AJ, Smith BD and others (2019) Bycatch in gillnet fisheries threatens Critically Endangered small cetaceans and other aquatic megafauna. Endang Species Res 40:285-296

Cairns J Jr (1999) Exemptionalism vs environmentalism: the crucial debate on the value of ecosystem health. Aquat Ecosys Health Manage 2:331-338

Ceballos G, Ehrlich PR, Dirzo R (2017) Biological annihila- tion via the ongoing sixth mass extinction signaled by vertebrate population losses and declines. Proc Natl Acad Sci USA 114:E6089-E6096

Chenoweth E, Stephan MJ (2011) Why civil resistance works: the strategic logic of nonviolent conflict. Columbia University Press, New York, NY

* Christensen V, Coll M, Piroddi C, Steenbeek J, Buszowski J, Pauly D (2014) A century of fish biomass decline in the ocean. Mar Ecol Prog Ser 512:155-166

* Chuenpagdee R, Morgan LE, Maxwell SM, Norse EA, Pauly D (2003) Shifting gears: assessing collateral impacts of fishing methods in US waters. Front Ecol Environ 1: 517-524

Claudet J, Loiseau C, Sostres M, Zupan M (2020) Underprotected Marine Protected Areas in a global biodiversity hotspot. One Earth 2:380-384

Coll M, Santojanni A, Palomera I, Arneri E (2009) Food-web changes in the Adriatic Sea over the last three decades. Mar Ecol Prog Ser 381:17-37

Commoner B (1973) Ecology and social action. University of California Press, Berkeley, CA

Corner A, Shaw C, Clarke J (2018) Principles for effective communication and public engagement on climate change: a handbook for IPCC authors. Climate Outreach, Oxford

Cullis-Suzuki S, Pauly D (2010) Marine protected area costs as 'beneficial' fisheries subsidies: a global evaluation. Coast Manage 38:113-121

* Cunsolo A, Ellis NR (2018) Ecological grief as a mental health response to climate change-related loss. Nat Clim Chang 8:275-281

DeLoach M, Bruner MS, Gossett JS (2002) An analysis of the 'tree-hugger' label. In: Meister M, Japp PM (eds) Enviropop: studies in environmental rhetoric and popular culture. Praeger, Westport, CT, p 95-110

* Devillers R, Pressey RL, Grech A, Kittinger JN, Edgar GJ, Ward T, Watson R (2015) Reinventing residual reserves in the sea: Are we favouring ease of establishment over need for protection? Aquat Conserv 25:480-504

* Díaz S, Settele J, Brondízio ES, Ngo HT and others (2019) Pervasive human-driven decline of life on Earth points to the need for transformative change. Science 366: eaax3100

* Dinerstein E, Vynne C, Sala E, Joshi AR and others (2019) A global deal for nature: funding principles, milestones, and targets. Sci Adv 5:eaaw2869

Doney SC (2010) The growing human footprint on coastal and open-ocean biogeochemistry. Science 328:1512-1516

* Duarte CM, Agusti S, Barbier E, Britten GL and others (2020) Rebuilding marine life. Nature 580:39-51

Dunlap RE, McCright AM (2015) Challenging climate change: the denial countermovement. In: Dunlap RE, Brulle RJ (eds) Climate change and society: sociological perspectives. Oxford University Press, New York, NY, p 300-332

Dunne J, Goleman D (2018) Ecology, ethics, and interdependence: the Dalai Lama in conversation with leading thinkers on climate change. Wisdom Publications, Somerville, MA

Dureuil M, Boerder K, Burnett KA, Froese R, Worm B (2018) Elevated trawling inside protected areas undermines conservation outcomes in a global fishing hot spot. Science 362:1403-1407

Earle S (2009) My wish: Protect our oceans. TED Talk, February 2009 [video]. www.ted.com/talks/sylvia_earle_my_ wish_protect_our_oceans 
Eckberg DL, Blocker TJ (1989) Varieties of religious involvement and environmental concerns: testing the Lynn White thesis. J Sci Stud Relig 28:509-517

Ecumenical Patriarch Bartholomew (2012) On Earth as in Heaven: ecological vision and initiatives of Ecumenical Patriarch Bartholomew. Fordham University Press, New York, NY

Ehrlich PR (1978) The population bomb. Ballantine, New York, NY

Ehrlich PR (1997) A world of wounds: ecologists and the human dilemma. Excellence in Ecology, Book 8. International Ecology Institute, Oldendorf/Luhe

Ehrlich PR, Ehrlich AH (2013) Can a collapse of global civilization be avoided? Proc Biol Sci 280:20122845

*Eigaard OR, Bastardie F, Hintzen NT, Buhl-Mortensen L and others (2017) The footprint of bottom trawling in European waters: distribution, intensity, and seabed integrity. ICES J Mar Sci 74:847-865

Epstein C (2005) The power of words in international relations: birth of an anti-whaling discourse. The MIT Press, Cambridge, MA

Ernman M, Thunberg G, Thunberg B, Thunberg S (2020) Our house is on fire: scenes of a family and a planet in crisis. Penguin, London

FAO (2018) The state of world fisheries and aquaculture 2018: meeting the sustainable development goals. FAO, Rome

Ferrà C, Tassetti AN, Grati F, Pellini G, Polidori P, Scarcella G, Fabi G (2018) Mapping change in bottom trawling activity in the Mediterranean Sea through AIS data. Mar Policy 94:275-281

Ferretti F, Osio GC, Jenkins CJ, Rosenberg AA, Lotze HK (2013) Long-term change in a meso-predator community in response to prolonged and heterogeneous human impact. Sci Rep 3:1057

Fortibuoni T, Giovanardi O, Pranovi F, Raicevich S, Solidoro C, Libralato S (2017) Analysis of long-term changes in a Mediterranean marine ecosystem based on fishery landings. Front Mar Sci 4:33

Fox HE, Kareiva P, Silliman B, Hitt J and others (2009) Why do we fly? Ecologists' sins of emission. Front Ecol Environ 7:294-296

Gambell R (1999) The International Whaling Commission and the contemporary whaling debate. In: Twiss JR Jr, Reeves RR (eds) Conservation and management of marine mammals. Smithsonian Institution Press, Washington, DC, p 179-198

Gates B (2018) My new favorite book of all time. GatesNotes, 26 January 2018. www.gatesnotes.com/Books/ Enlightenment-Now

* Gissi E, Menegon S, Sarretta A, Appiotti F and others (2017) Addressing uncertainty in modelling cumulative impacts within maritime spatial planning in the Adriatic and Ionian region. PLOS ONE 12:e0180501

* Gordon TA, Radford AN, Simpson SD (2019) Grieving environmental scientists need support. Science 366:193

Guidetti P, Milazzo M, Bussotti S, Molinari A (2008) Italian marine reserve effectiveness: Does enforcement matter? Biol Conserv 141:699-709

* Hagedorn G, Kalmus P, Mann M, Vicca S and others (2019) Concerns of young protesters are justified. Science 364 : 139-140

Halfar J, Fujita RM (2007) Danger of deep-sea mining. Science 316:987

Hall-Spencer JM, Froglia C, Atkinson RJA, Moore PG (1999)
The impact of rapido trawling for scallops, Pecten jacobaeus (L.), on the benthos of the Gulf of Venice. ICES J Mar Sci 56:111-124

Halpern BS, Walbridge S, Selkoe KA, Kappel CV and others (2008) A global map of human impact on marine ecosystems. Science 319:948-952

*Halpern BS, Frazier M, Potapenko J, Casey KS and others (2015) Spatial and temporal changes in cumulative human impacts on the world's ocean. Nat Commun 6: 7615

Hassol SJ (2008) Improving how scientists communicate about climate change. EOS Trans Am Geophys Union 89: 106-107

*Hausfather Z (2019) UNEP: 1.5C climate target 'slipping out of reach'. CarbonBrief, 26 November 2019. www. carbonbrief.org/unep-1-5c-climate-target-slipping-outof-reach

*Hedenus F, Wirsenius S, Johansson DJ (2014) The importance of reduced meat and dairy consumption for meeting stringent climate change targets. Clim Change 124: 79-91

KHiggins P, Short D, South N (2013) Protecting the planet: a proposal for a law of ecocide. Crime Law Soc Change 59: 251-266

Hobbs RJ (2013) Grieving for the past and hoping for the future: balancing polarizing perspectives in conservation and restoration. Restor Ecol 21:145-148

*Hoegh-Guldberg O, Mumby PJ, Hooten AJ, Steneck RS and others (2007) Coral reefs under rapid climate change and ocean acidification. Science 318:1737-1742

*Hughes TP, Baird AH, Bellwood DR, Card M and others (2003) Climate change, human impacts, and the resilience of coral reefs. Science 301:929-933

*Hughes TP, Anderson KD, Connolly SR, Heron SF and others (2018a) Spatial and temporal patterns of mass bleaching of corals in the Anthropocene. Science 359:80-83

*Hughes TP, Kerry JT, Baird AH, Connolly SR and others (2018b) Global warming transforms coral reef assemblages. Nature 556:492-496

Hutchings K (2005) Don't call me a tree hugger!: sticks, stones, and stereotypes in ecocriticism. Interdiscip Lit Stud 7:5-26

*Huxley TH (1885) Inaugural address, International Fisheries Exhibition London 1883. The Fisheries Exhibition Literature, Scientific Memoirs 5. http://mathcs.clarku.edu/ huxley/SM5/fish.html

* IPCC (International Panel on Climate Change) (2018) Global warming of $1.5^{\circ} \mathrm{C}$. An IPCC special report on the impacts of global warming of $1.5^{\circ} \mathrm{C}$ above pre-industrial levels and related global greenhouse gas emission pathways, in the context of strengthening the global response to the threat of climate change, sustainable development, and efforts to eradicate poverty. World Meteorological Organization, Geneva. www.ipcc.ch/sr15/download/

IPCC (2019) IPCC special report on the ocean and cryosphere in a changing climate. Intergovernmental Panel on Climate Change. www.ipcc.ch/srocc/download-report-2/

* Jackson JBC, Kirby MX, Berger WH, Bjorndal KA and others (2001) Historical overfishing and the recent collapse of coastal ecosystems. Science 293:629-637

Jackson JBC, Alexander KE, Sala E (2011) Shifting baselines: the past and the future of ocean fisheries. Island Press, Washington, DC

Jacquet J, Pauly D, Ainley D, Holt S, Dayton P, Jackson J (2010a) Seafood stewardship in crisis. Nature 467:28-29 
Jacquet J, Hocevar J, Lai S, Majluf P and others (2010b) Conserving wild fish in a sea of market-based efforts. Oryx 44:45-56

Jacquet J, Sebo J, Elder M (2017) Seafood in the future: Bivalves are better. Solutions 8:27-32

Jessen B, Black J, Cormier R, Gabela A and others (2006) In: Norse EA, Crowder LB (eds) Review of 'Marine conservation biology: the science of maintaining the sea's biodiversity'. Rev Fish Biol Fisher 16:229-231

Johnson AE (2019) A love story for the coral reef crisis. TED Talk, April 2019 [video]. www.ted.com/talks/ayana_ elizabeth_johnson_a_love_story_for_the_coral_reef_crisis

Jones JB (1992) Environmental impact of trawling on the seabed: a review. N Z J Mar Freshw Res 26:59-67

Jørgensen D (2015) Rethinking rewilding. Geoforum 65: 482-488

Kaiser MJ, Collie JS, Hall SJ, Jennings S, Poiner IR (2002) Modification of marine habitats by trawling activities: prognosis and solutions. Fish Fish 3:114-136

Kelly MJ (2013) Why a collapse of global civilization will be avoided: a comment on Ehrlich \& Ehrlich. Proc Biol Sci 280:20131193

Korten DC (2010) Agenda for a new economy: from phantom wealth to real wealth. Berrett-Koehler, San Francisco, CA

Korten DC (2015) Change the story, change the future: a living economy for a living Earth. Berrett-Koehler, Oakland, CA

Kulp SA, Strauss BH (2019) New elevation data triple estimates of global vulnerability to sea-level rise and coastal flooding. Nat Commun 10:4844

Kurlansky M (1997) Cod: a biography of the fish that changed the world. Walker, New York, NY

Laffoley D, Baxter JM, Amon DJ, Currie DE and others (2020) Eight urgent, fundamental and simultaneous steps needed to restore ocean health, and the consequences for humanity and the planet of inaction or delay. Aquat Conserv 30:194-208

Ke Manach F, Jacquet JL, Bailey M, Jouanneau C, Nouvian C (2020) Small is beautiful, but large is certified: a comparison between fisheries the Marine Stewardship Council (MSC) features in its promotional materials and MSC-certified fisheries. PLOS ONE 15:e0231073

Lent J (2017) The patterning instinct: a cultural history of humanity's search for meaning. Prometheus Books, New York, NY

Lent J (2018) Steven Pinker's ideas about progress are fatally flawed: These eight graphs show why. Patterns of Meaning, 17 May 2018. http://patternsofmeaning.com/

Lent J (2019) What will you say to your grandchildren? Patterns of Meaning, 11 April 2019. http://patternsofmeaning.com/

Lenton TM, Rockström J, Gaffney O, Rahmstorf S, Richardson K, Steffen W, Schellnhuber HJ (2019) Climate tipping points - too risky to bet against. Nature 575:592-595

Levin LA, Le Bris N (2015) The deep ocean under climate change. Science 350:766-768

Lotze HK, Coll M, Dunne JA (2011) Historical changes in marine resources, food-web structure and ecosystem functioning in the Adriatic Sea, Mediterranean. Ecosystems 14:198-222

Lucchetti A, Sala A (2012) Impact and performance of Mediterranean fishing gear by side-scan sonar technology. Can J Fish Aquat Sci 69:1806-1816

* Lukacs M (2017) Neoliberalism has conned us into fighting climate change as individuals. The Guardian, 17 July 2017. https://www.theguardian.com/environment/truenorth/2017/jul/17/neoliberalism-has-conned-us-intofighting-climate-change-as-individuals

*Machovina B, Feeley KJ, Ripple WJ (2015) Biodiversity conservation: The key is reducing meat consumption. Sci Total Environ 536:419-431

Mares D (2010) Criminalizing ecological harm: crimes against carrying capacity and the criminalization of ecosinners. Crit Criminol 18:279-293

Marshall G (2015) Don't even think about it: why our brains are wired to ignore climate change. Bloomsbury, New York, NY

McGoey L (2019) The unknowers: how strategic ignorance rules the world. Zed Books, London

McKibben B (1989) The end of nature. Random House, New York, NY

McKibben B (2019) Falter: Has the human game begun to play itself out? Henry Holt, New York, NY

*McLeod E, Palmer M (2015) Why conservation needs religion. Coast Manage 43:238-252

Meadows DH, Meadows DL, Randers J, Behrens WW (1972) The limits to growth. Universe Books, New York, NY

Meadows D, Randers J, Meadows D (2005) The limits to growth: the 30-year update. Earthscan, London

Meffe GK (1998) Conservation scientists and the policy process. Conserv Biol 12:741-742

Mitchell RB (2019) International Environmental Agreements Database Project, version 2018.1. http://iea.uoregon.edu/

Monbiot G (2006) Heat: how to stop the planet burning. Allen Lane, London

Monbiot G (2013) Feral: searching for enchantment on the frontiers of rewilding. Penguin, London

Monbiot G (2018) You can deny environmental calamityuntil you check the facts. The Guardian, 7 March 2018. https://www.theguardian.com/commentisfree/2018/mar /07/environmental-calamity-facts-steven-pinker

Mora C, Spirandelli D, Franklin EC, Lynham J and others (2018) Broad threat to humanity from cumulative climate hazards intensified by greenhouse gas emissions. Nat Clim Chang 8:1062-1071

Morris J (2009) The persistence of population pessimism. Electron J Sustain Dev 1:1-3

Mowat F (1984) Seas of slaughter. Key Porter Books, Toronto, $\mathrm{ON}$

Negi CS (2005) Religion and biodiversity conservation: not a mere analogy. Int J Biodivers Sci Manage 1:85-96

Nekola JC, Allen CD, Brown JH, Burger JR and others (2013) The Malthusian-Darwinian dynamic and the trajectory of civilization. Trends Ecol Evol 28:127-130

Norse EA, Crowder LB (2005) Marine conservation biology: the science of maintaining the sea's biodiversity. Island Press, Washington, DC

${ }^{\prime}$ 'Neill DW, Fanning AL, Lamb WF, Steinberger JK (2018) A good life for all within planetary boundaries. Nature Sustain 1:88-95

* Oransky I, Marcus A (2017) Should scientists engage in activism? The Conversation, 7 February 2017. https://the conversation.com/should-scientists-engage-in-activism72234

Oreskes N, Conway EM (2010) Merchants of doubt: how a handful of scientists obscured the truth on issues from tobacco smoke to global warming. Bloomsbury, New York, NY

Páez-Osuna F (2001) The environmental impact of shrimp 
aquaculture: causes, effects, and mitigating alternatives. Environ Manage 28:131-140

Pasanen J (2019) Individual change or system change is not the right question. Jussi Pasanen blog. www.jussipasanen.com/individual-change-or-system-change-is-notthe-right-question/

Pauly D (1995) Anecdotes and the shifting baseline syndrome of fisheries. Trends Ecol Evol 10:430

Pauly D (2019) Vanishing fish: shifting baselines and the future of global fisheries. Greystone Books, Vancouver, $\mathrm{BC}$

Pauly D, Christensen V, Dalsgaard J, Froese R, Torres F Jr (1998) Fishing down marine food webs. Science 279: 860-863

Payne RK (2010) How much is enough? Buddhism, consumerism, and the human environment. Wisdom Publications, Somerville, MA

Pettifor A (2019) The case for the Green New Deal. Verso, London

Pielke RA (2004) When scientists politicize science: making sense of controversy over The Skeptical Environmentalist. Environ Sci Policy 7:405-417

Pinker S (2011) The better angels of our nature: why violence has declined. Viking, New York, NY

Pinker S (2018) Enlightenment now: the case for reason, science, humanism, and progress. Penguin, New York, NY

* Piroddi C, Bearzi G, Gonzalvo Villegas J, Christensen V (2011) From common to rare: the case of the Mediterranean common dolphin. Biol Conserv 144:2490-2498

Poore J, Nemecek T (2018) Reducing food's environmental impacts through producers and consumers. Science 360: 987-992

Pope Francis (2015) Laudato si': on care for our common home. Libreria Editrice Vaticana, Vatican City

Pranovi F, Raicevich S, Franceschini G, Farrace MG, Giovanardi O (2000) Rapido trawling in the northern Adriatic Sea: effects on benthic communities in an experimental area. ICES J Mar Sci 57:517-524

Raworth K (2017) Doughnut economics: seven ways to think like a 21st-century economist. Chelsea Green Publishing, White River Junction, VT

Reeves RR (2018) Conservation. In: Würsig B, Thewissen JGM, Kovacs KM (eds) Encyclopedia of marine mammals, 3rd edn. Academic Press, San Diego, CA, p 215-229

Reid PC, Fischer AC, Lewis-Brown E, Meredith MP and others (2009) Impacts of the oceans on climate change. Adv Mar Biol 56:1-150

Rieser A, Grey Hudson C, Roady SE (2005) The role of legal regimes in marine conservation. In: Norse EA, Crowder LB (eds) Marine conservation biology: the science of maintaining the sea's biodiversity. Island Press, Washington, DC, p 362-374

Ripple WJ, Smith P, Haberl H, Montzka SA, McAlpine C, Boucher DH (2014) Ruminants, climate change and climate policy. Nat Clim Chang 4:2-4

Ripple WJ, Wolf C, Newsome TM, Galetti M and others (2017) World scientists' warning to humanity: a second notice. BioScience 67:1026-1028

Ripple WJ, Wolf C, Newsome TM, Barnard P, Moomaw WR (2020) World scientists' warning of a climate emergency. BioScience 70:8-12

Riskin J (2019) Pinker's Pollyannish philosophy and its perfidious politics. Los Angeles Review of Books, 15 December 2019. https://lareviewofbooks.org/article/pinkerspollyannish-philosophy-and-its-perfidious-politics/
Roberts CM (2002) Deep impact: the rising toll of fishing in the deep sea. Trends Ecol Evol 17:242-245

Roberts CM, Hawkins JP, Gell FR (2005) The role of marine reserves in achieving sustainable fisheries. Philos Trans R Soc B 360:123-132

Roman J, Altman I, Dunphy-Daly MM, Campbell C, Jasny M, Read AJ (2013) The Marine Mammal Protection Act at 40: status, recovery, and future of US marine mammals. Ann N Y Acad Sci 1286:29-49

Rosling H, Rosling O, Rosling Rönnlund A (2018) Factfulness: ten reasons we're wrong about the world-and why things are better than you think. Flatiron Books, New York, NY

* Ruggiero V, South N (2010a) Critical criminology and crimes against the environment. Crit Criminol 18:245-250

* Ruggiero V, South N (2010b) Green criminology and dirty collar crime. Crit Criminol 18:251-262

* Ruggiero V, South N (2013) Green criminology and crimes of the economy: theory, research and praxis. Crit Criminol 21:359-373

* Running SW (2013) Approaching the limits. Science 339: 1276-1277

Kusso T, Carpentieri P, D'Andrea L, De Angelis P and others (2019) Trends in effort and yield of trawl fisheries: a case study from the Mediterranean Sea. Front Mar Sci 6:153

Sapolsky RM (2017) Behave: the biology of humans at our best and worst. Penguin Press, New York, NY

Scheer H (2012) The energy imperative: 100 percent renewable now. Earthscan, London

Sedlak D (2016) Crossing the imaginary line. Environ Sci Technol 50:9803-9804

Smith TD (2002) A history of fisheries and their science and management. In: Hart PJB, Reynolds JD (eds) Handbook of fish biology and fisheries, Vol 2. Blackwell Science, Malden, MA, p 61-83

Solomon S, Ivy DJ, Kinnison D, Mills MJ, Neely RR III, Schmidt A (2016) Emergence of healing in the Antarctic ozone layer. Science 353:269-274

Somerville RC, Hassol SJ (2011) Communicating the science of climate change. Phys Today 64:48-52

Stanley J, Loy DR, Dorje G (2009) A Buddhist response to the climate emergency. Wisdom Publications, Boston, MA

Steffen W, Rockström J, Richardson K, Lenton TM and others (2018) Trajectories of the Earth system in the Anthropocene. Proc Natl Acad Sci USA 115:8252-8259

* Stehfest E, Bouwman L, Van Vuuren DP, Den Elzen MG, Eickhout B, Kabat P (2009) Climate benefits of changing diet. Clim Change 95:83-102

Stephan MJ, Chenoweth E (2008) Why civil resistance works: the strategic logic of nonviolent conflict. Int Secur 33:7-44

Stewart BD, Howarth LM, Wood H, Whiteside K and others (2020) Marine conservation begins at home: How a local community and protection of a small bay sent waves of change around the UK and beyond. Front Mar Sci 7:76

Sumaila UR, Lam V, Le Manach F, Swartz W, Pauly D (2016) Global fisheries subsidies: an updated estimate. Mar Policy 69:189-193

Dalai Lama [Tenzin Gyatso] (2005) The universe in a single atom. Morgan Road Books, New York, NY

* Tong D, Zhang Q, Zheng Y, Caldeira K and others (2019) Committed emissions from existing energy infrastructure jeopardize $1.5^{\circ} \mathrm{C}$ climate target. Nature 572:373-377

Tønnessen JN, Johnsen AO (1982) The history of modern whaling. University of California Press, Berkeley, CA 
Turner GM (2008) A comparison of The Limits to Growth with 30 years of reality. Glob Environ Change 18:397-411

Twiss JR Jr, Reeves RR (1999) Conservation and management of marine mammals. Smithsonian Institution Press, Washington, DC

UNEP (United Nations Environment Programme) (2019) Emissions Gap Report 2019. UNEP, Nairobi

Vitousek PM, Mooney HA, Lubchenco J, Melillo JM (1997) Human domination of Earth's ecosystems. Science 277: 494-499

Warren M (2019) Thousands of scientists are backing the kids striking for climate change. Nature 567:291-292

Editorial responsibility: Darryl Macer,

Scottsdale, Arizona, USA
Washington H, Cook J (2011) Climate change denial: heads in the sand. Earthscan, London

*White L Jr (1967) The historical roots of our ecologic crisis. Science 155:1203-1207

White R (2013) Crimes against nature: environmental criminology and ecological justice. Routledge, London

White R (2016) Transnational environmental crime. Routledge, London

Wilson EO (1999) Consilience: the unity of knowledge. Vintage Books, New York, NY

Wilson EO (2006) The creation: an appeal to save life on Earth. Norton, New York, NY

Submitted: January 20, 2020; Accepted: March 25, 2020

Proofs received from author(s): May 27, 2020 